\title{
Monitoring of Sparta Aquifer Recovery in Southern Arkansas and Northern Louisiana, 2003-07
}

Prior to 2004, the Sparta aquifer supplied all water for industrial and municipal uses in Union County, Arkansas, and continues to provide the majority of water for industrial and municipal purposes in the surrounding southern Arkansas counties and northern Louisiana parishes. In Union County, the Sparta aquifer has been used increasingly since development began in the early 1920s, resulting in water-level declines of more than 360 feet (ft) near El Dorado, Arkansas (Scheiderer and Freiwald, 2006). In addition, water quality in some areas of the Sparta aquifer has degraded with increased withdrawals (Scheiderer and Freiwald, 2006).

In 1996, in response to declining water levels and degraded water quality in the Sparta aquifer, the Arkansas Natural Resources Commission designated a "Critical Ground-Water Area" in five southern Arkansas counties-Bradley, Calhoun, Columbia, Ouachita, and Union. U.S. Geological Survey (USGS) ground-water flow models indicated that Sparta aquifer withdrawals in Union County would need to be reduced to 28 percent of 1997 withdrawals, about 6 million gallons per day $(\mathrm{Mgal} / \mathrm{d})$, to recover and maintain the aquifer's sustainable yield resulting in water levels at or above the top of the Sparta Sand (Hays, 2000).

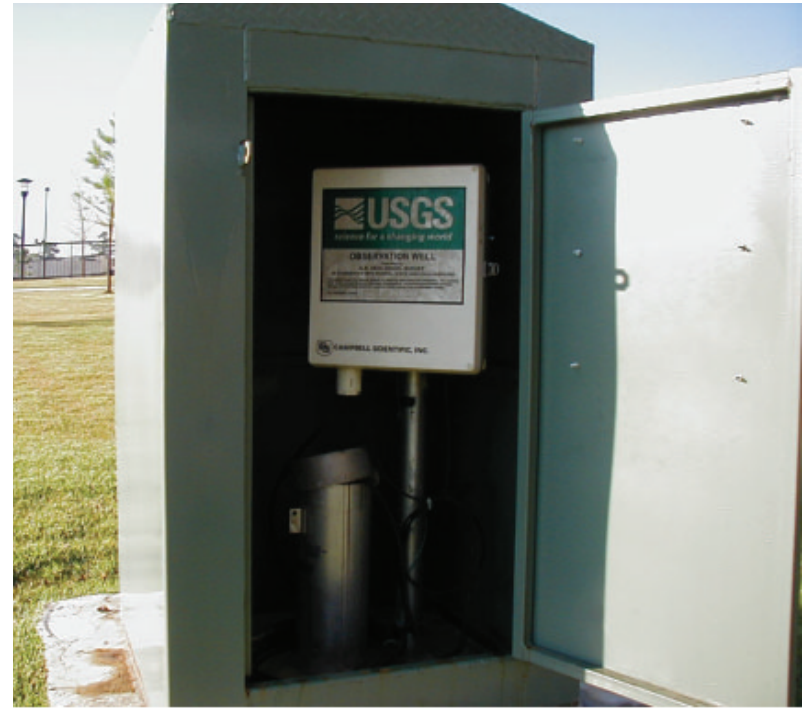

Figure 1. Welcome Center real-time well southeast of El Dorado, Arkansas (photograph by David Freiwald, U.S. Geological Survey).

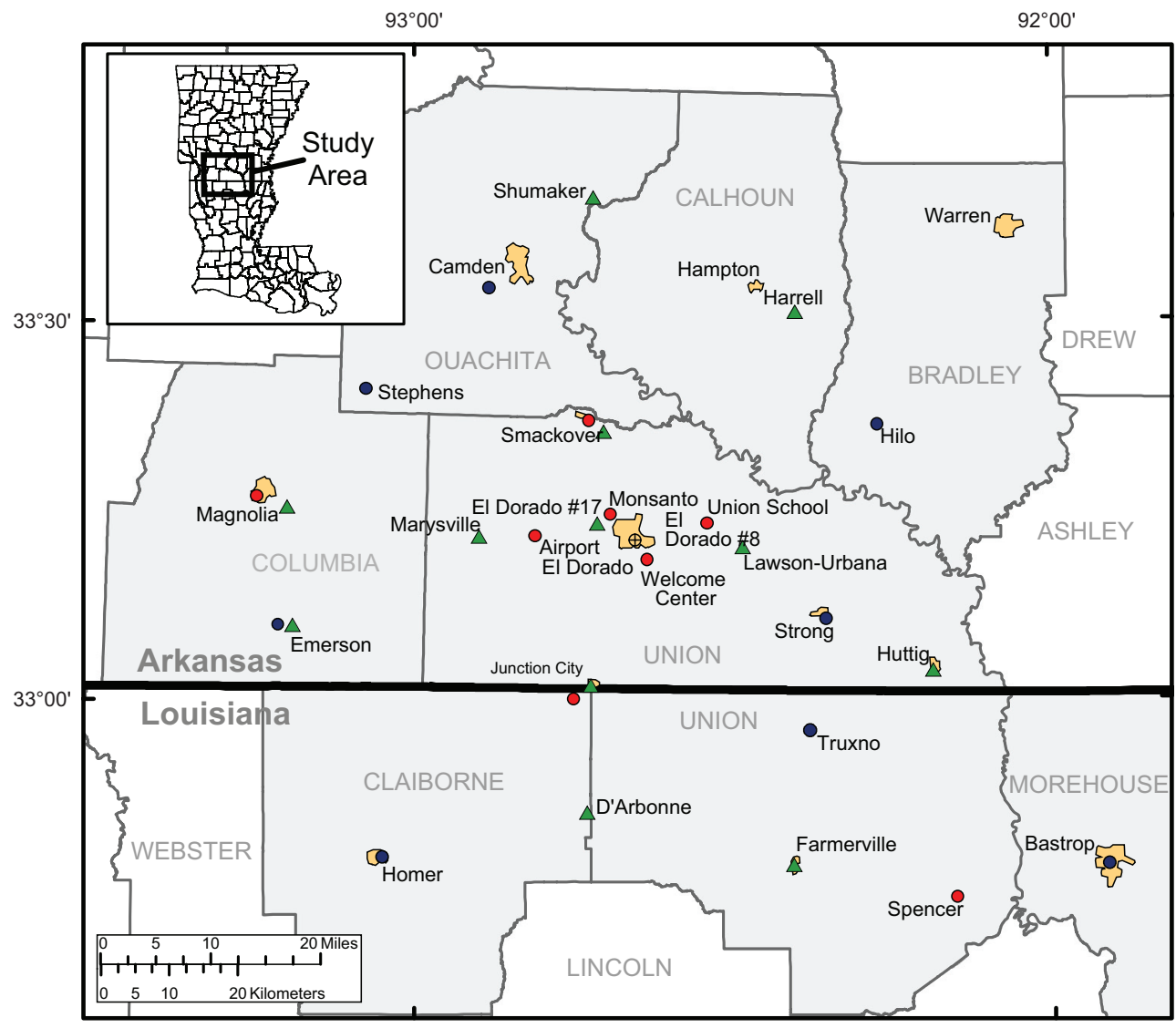

\section{EXPLANATION}

- U.S. Geological Survey Real-Time Well

- Union County Conservation District Automatic Data Logger Well

$\oplus \quad$ El Dorado Water Users Monitoring Well

$\Delta$ U.S. Geological Survey Water-Quality Monitoring Well

Figure 2. Location of water-level and water-quality monitoring wells. 


\section{Background}

To prevent further Sparta aquifer water-level declines, stakeholders in Union County initiated conservation and ground-water reuse and tapped a surface-water supply as an alternative source for Union County's three largest industrial users. A pumping station and pipeline completed in 2004 supplies approximately $4.8 \mathrm{Mgal} / \mathrm{d}$ of Ouachita River surface water to the three industrial users that previously relied solely on Sparta aquifer water: El Dorado Chemical, Chemtura, and Lion Oil.

With a reduction in Sparta aquifer ground-water withdrawals, ground-water models projected that water levels would rise and water quality should improve or stabilize. Formed in 1999 as authorized by Act 1050 of 1999 of the Arkansas General Assembly, the Union County Water Conservation Board (UCWCB) has authority over ground water. The UCWCB built the surface-water infrastructure, the Ouachita River Alternative Water Supply Project (Reynolds and others, 2006), and in 2002 implemented a cooperative study with the USGS, U.S. Environmental Protection Agency (EPA), Union County Conservation District (UCCD), and Burns \& McDonnell engineering firm to monitor Sparta aquifer water-level recovery. The study measures, through monitoring and reporting of water levels in Sparta aquifer wells throughout the study area, the impact of conservation and alternative water efforts on water level and water quality (Yeatts, 2004; Scheiderer and Freiwald, 2006).

This study provides continuous real-time water-level data at http://ar.water.usgs.gov and www.ucwcb.org from eight USGS wells that are part of a network of 29 monitoring wells in southern Arkansas and northern Louisiana (figs. 1 and 2), and periodically reports results of semi-annual water-quality sampling. In addition to the eight USGS real-time wells, the UCCD maintains and posts water-level data from eight wells with automated (computerized measurements) data loggers in the five-county/three-parish study area. All data were reported in semi-annual reports to EPA and are available at www.ucwcb.org. This fact sheet describes ground-water level and water-quality monitoring activities for the Sparta aquifer recovery study and results for 2003-07.

\section{Ground-Water Level Monitoring}

The USGS conducts real-time water-level monitoring in eight wells and updates water-level data on the USGS and UCWCB Web sites four times per day. Ground-water level monitoring wells were selected from six existing and two drilled wells in and around Union County in 2003 to form the ground-water level monitoring network (fig. 2).

One of the three criteria for Critical Ground-Water Area designation occurs when water levels fall below the top of the formation (Pugh and others, 1998; Brantly and others, 2002) for a confined aquifer. Water levels for seven of the eight real-time wells continue to meet these Critical Ground-Water Area criteria. As of May 2007, water levels in the Sparta aquifer range from $64 \mathrm{ft}$ above the top of the Sparta Sand in the Spencer well in southeastern Union Parish, Louisiana, to $85 \mathrm{ft}$ below the top of the Sparta Sand in the Airport well near El Dorado where the lowest water levels historically have occurred (Schrader and Jones, 2007).

However, water levels have risen in all eight real-time wells since monitoring began in the summer of 2003 (fig. 3), and the Ouachita River Alternative Water Supply Project was completed in September 2004. In December 2004, Lion Oil converted from using ground water to surface water from the Ouachita River. In February and October 2005, the UCWCB supplied surface water to El Dorado Chemical and Chemtura, respectively (fig. 3). Combined with previous conservation efforts, the industrial users' conversion to surface water reduced Union County ground-water withdrawals by approximately $7.5 \mathrm{Mgal} / \mathrm{d}$. The largest water-level rises occurred between October 2004 and April 2007 in the Monsanto well $(49.0 \mathrm{ft}$ rise) just north of El Dorado, and the Welcome Center well (36.1 ft rise) southeast of El Dorado (fig. 4). The Spencer, Louisiana, well had the smallest rise (1.6 ft) during the October 2004 and April 2007 period. Seasonal fluctuations in water levels occur as a result of increased ground-water withdrawals in the summer (fig. 3). Groundwater levels generally are highest in the spring and lowest in the summer.

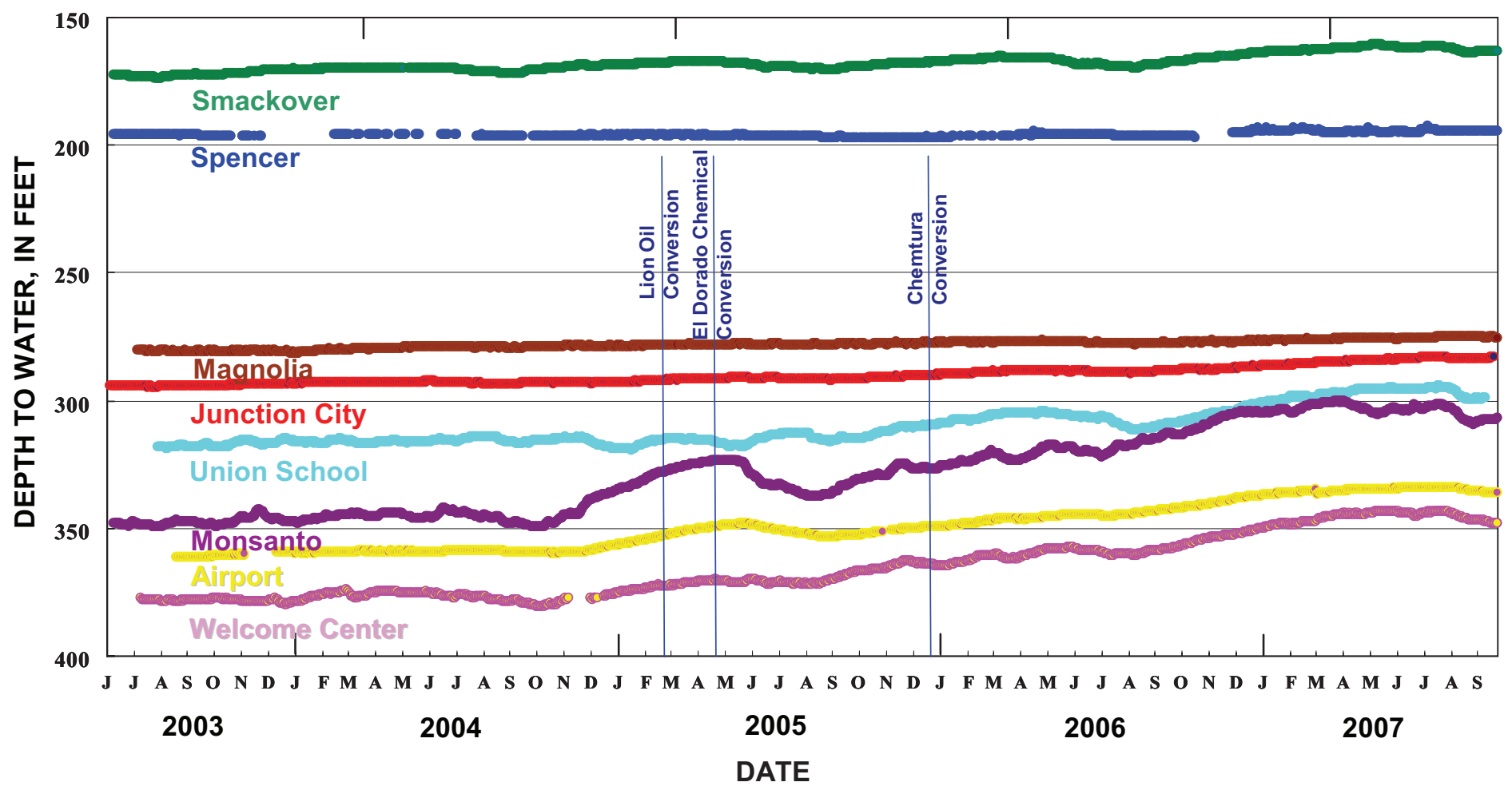

Figure 3. Hydrograph showing water levels for U.S. Geological Survey real-time wells and industrial conversion to surface-water supplies. 


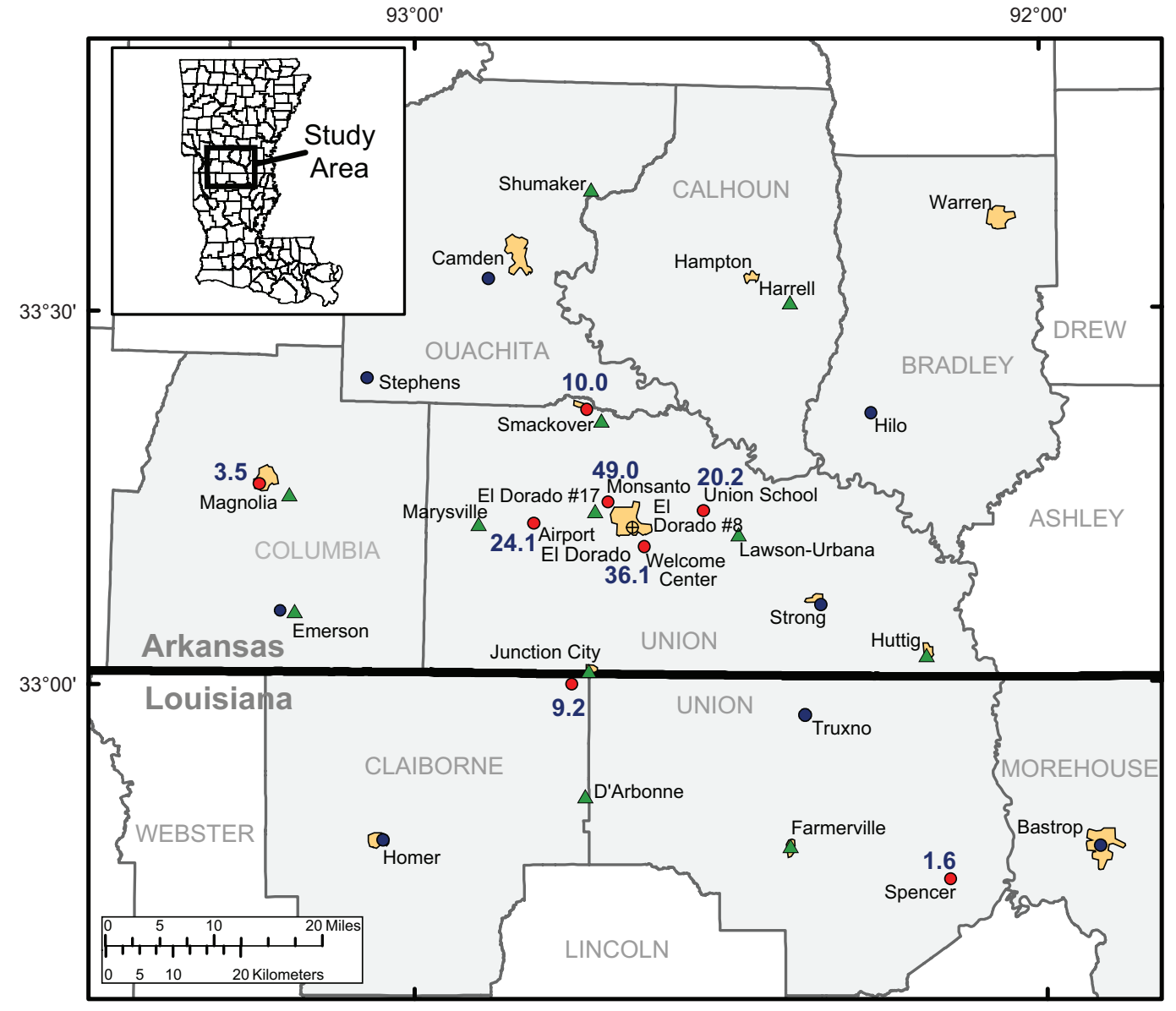

EXPLANATION

- U.S. Geological Survey Real-Time Well

- Union County Conservation District Automatic Data Logger Well

$\oplus \quad$ El Dorado Water Users Monitoring Well

$\triangle$ U.S. Geological Survey Water-Quality Monitoring Well

36.1 Rise in water level, in feet, between October 2004 and April 2007

Figure 4. Water-level change for U.S. Geological Survey real-time wells between October 2004 and April 2007.

\section{Water-Quality Monitoring}

Another concern in the study area is water-quality degradation, or a threat of degradation. Between 2003 and 2007, water-quality samples were collected from 12 existing public or industrial supply wells throughout the study area selected as water-quality monitoring wells (fig. 2). Wells were sampled semi-annually (January and July) for specific conductance and chloride concentration. Changes in specific conductance and chloride concentration in ground water are useful in determining areas affected by saltwater (high-salinity water) encroachment. If enough freshwater is withdrawn from a ground-water system, water with higher salinity can flow into the system to replace the withdrawn freshwater. The higher salinity water may flow upward from deeper systems as well as laterally from areas containing saltwater (Scheiderer and Freiwald, 2006).

Results of semi-annual water-quality samples collected from January 2003 to July 2007 show no trends or major changes through time (fig. 5). Water-quality data from the Farmerville, Louisiana, well did show some extremes, however, with specific conductance ranging from 753 microsiemens per centimeter at 25 degrees Celsius $(\mu \mathrm{S} / \mathrm{cm})$ to $1,780 \mu \mathrm{S} / \mathrm{cm}$, and chloride concentrations ranging from 90 milligrams per liter $(\mathrm{mg} / \mathrm{L})$ to $221 \mathrm{mg} / \mathrm{L}$.

Specific conductance and chloride concentration increases toward the southeast in the study area. Average specific conductance from individual wells ranges from 216 in the northwest to $1,157 \mu \mathrm{S} / \mathrm{cm}$ in the southeast and average chloride concentration ranges from 3.2 to $214 \mathrm{mg} / \mathrm{L}$. The highest maximum and average specific conductance and chloride concentrations occur in samples from Farmerville, Louisiana, and Huttig, Arkansas, in the southeastern part of the study area with average specific conductance greater than $1,150 \mu \mathrm{S} / \mathrm{cm}$ and average chloride concentrations greater than $175 \mathrm{mg} / \mathrm{L}$. The results coincide with more regional specific conductance and chloride concentration results (Schrader and Jones, 2007). The EPA's National Secondary Drinking Water Regulation for chloride concentration in public water supply is $250 \mathrm{mg} / \mathrm{L}$. There is no standard or regulation for specific conductance.

Wells sampled in the northwestern part of the study area (Shumaker, Marysville, Magnolia, and Emerson, Arkansas) have average specific conductance values less than $400 \mu \mathrm{S} / \mathrm{cm}$ and average chloride concentration less than $10 \mathrm{mg} / \mathrm{L}$. The minimum specific conductance was $162 \mu \mathrm{S} / \mathrm{cm}$ at Shumaker, and the minimum chloride concentration was $3.0 \mathrm{mg} / \mathrm{L}$ at Emerson.

\section{References}

Brantly, J.A., Seanor, R.C., and McCoy, K.L., 2002, Louisiana ground-water map no. 13: Hydrogeology and potentiometric surface, October 1996, of the Sparta aquifer in northern Louisiana: U.S. Geological Survey Water-Resources Investigations Report 02-4053, 3 plates.

Hays, P.D., 2000, Sustainable yield estimation for the Sparta aquifer in Union County, Arkansas: U.S. Geological Survey Water-Resources Investigations Report 99-4272, 17 p.

Pugh, A.L., Westerfield, P.W., Gonthier, G.J., and Poynter, D.T., 1998, Altitude of the top of the Sparta Sand in three areas of Arkansas: U.S. Geological Survey Water-Resources Investigations Report 98-4002, 5 p. 


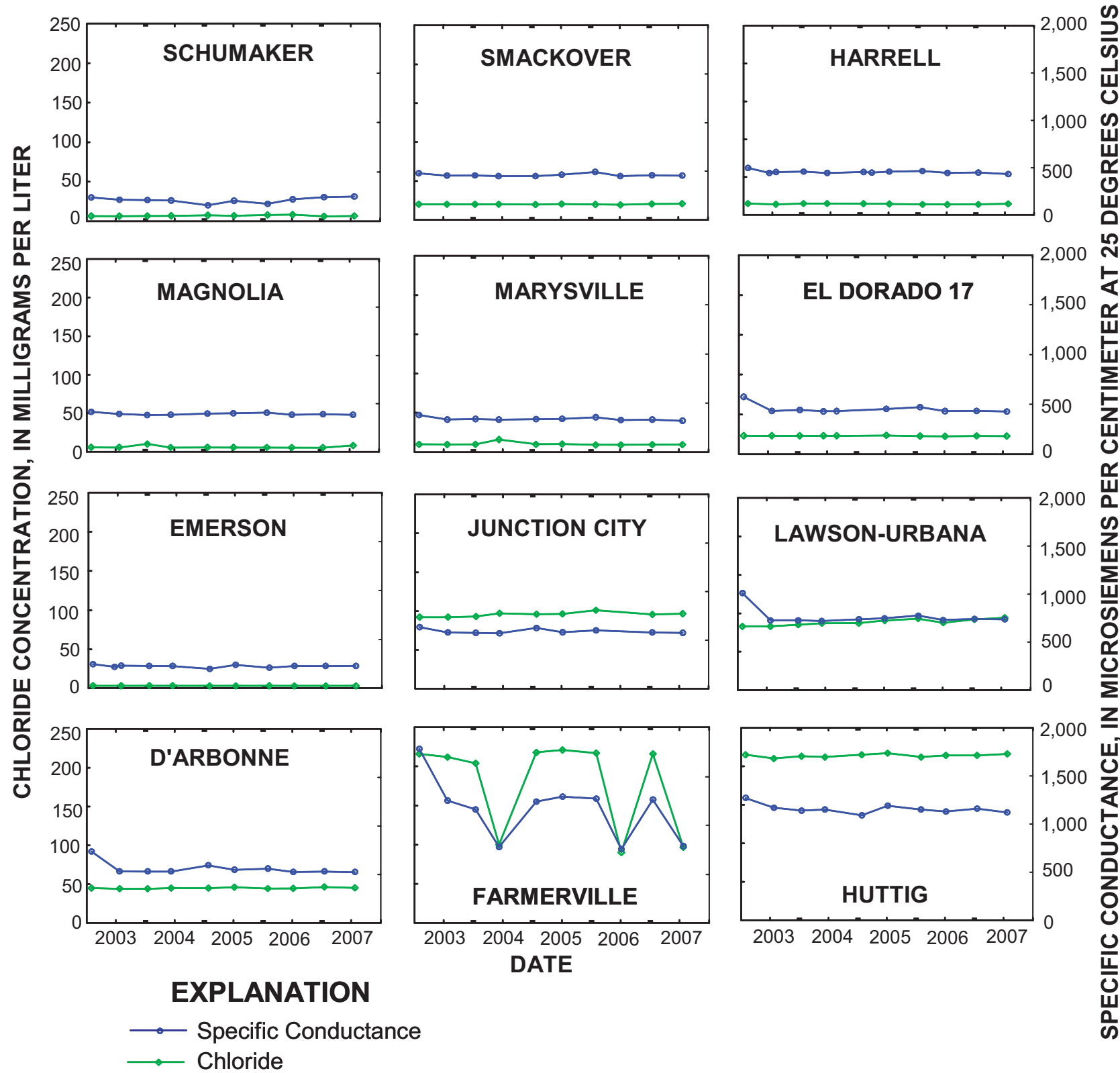

Figure 5. Specific conductance and chloride concentration results for U.S. Geological Survey water-quality monitoring wells.

Reynolds, R.M., Johnson, S.F., and Union County (Arkansas) Water Conservation Board, 2006, Ouachita River Alternative Water Supply Project: http://argis.ualr.edu/website/unionCoGraph/images/ ProjectDescriptionJan06.pdf, 10 p.

Scheiderer, R.M. and Freiwald, D.A., 2006, Monitoring the recovery of the Sparta aquifer in southern Arkansas and northern Louisiana: U.S. Geological Survey Fact Sheet 2006-3090, 4 p.

Schrader, T.P. and Jones, J.S., 2007, Status of water levels and selected water-quality conditions in the Sparta-Memphis aquifer in Arkansas and the status of water levels in the Sparta aquifer in Louisiana, spring 2005: U.S. Geological Survey Scientific Investigations Report 2007-5029, 66 p.

Yeatts, D.S., 2004, Monitoring water-level and water-quality response to conservation measures in the Sparta aquifer of the Union County, Arkansas area: U.S. Geological Survey Fact Sheet 2004-3086, 4 p.

-David A. Freiwald, U.S. Geological Survey and Sherrel F. Johnson, Union County Water Conservation Board
Information on technical reports and hydrologic data related to this study can be obtained from:

Director

USGS Arkansas Water Science Center

401 Hardin Road

Little Rock, AR 72211

http://arwater.usgs.gov/

E-mail: dc_ar@usgs.gov

Phone: (501) 228-3600

Fax: (501) 228-3601

For additional information on the Union County study contact:

Cindy Woolsey, Administrative Assistant

Union County Water Conservation Board

E-mail: cindywoolsey@suddenlink.net

Phone: (870) 862-1244

http//www.ucwcb.org 